K. H. Kim, T. T. Tchen and F. Hu showed that when skin of xanthic goldfish produces melanocytes a cell division is involved; presumably the melano. blasts do not become melenocytes, but produce them.

G. Cleffmann presented a very impressive study of the mode of action of genes at the agouti locus in the mouse. He showed that yellow or black pigment production is not the result of intrinsic differences in the pigment cell system, but that it is determined by the environment of the melanocytes; there is considerable evidence of the importance of sulphydryl groups.

Vernon Riley has evidence from very many tumour lines, in mice, of the existence of a serially transmissible virus-like factor, which is associated with high lactic dehydrogenase-levels in the body fluids. 'Virus-free' tumours newly induced by methylcholanthrene increased their capacity for anaerobic glycolysis five-fold after infection with the tumour; and blood lactic dehydrogenase-level rose 200 -fold. Such results from the serially propagated lines is now, therefore, suspect.

Work on the mechanism of induction of melanoma in Drosophila and on the 'induced genetic change' resulting appeared, at presentation, to suffer from almost total absence of control experiments. Any generalizations from these results may well be premature. A paper by H. W. Lewis, in great contrast to the previous Drosophila papers, correlated genetic change with tyrosinase activity and lability, a specific tyrosinase activator (protein) and dialysable and non-dialysable inhibitors of the activated enzyme.

The eighth and ninth (final) sessions were devoted to "Molecular and Macromolecular Aspects of Melanogenesis" and included a paper by A. S. Fox and J. B. Burnett which dealt with a system from Neurospora which was substantially similar to Lewis's Drosophila system. These sessions also included discussions of such diverse topics as the importance of pterins in the pigmentation of fish and amphibians (T. Hama), the biochemical role of mitochondria (K. Giger), and the use of chromatography to detect the presence of melanin in the urine of a patient with metastatic melanoma (E. Ghislandi). The beautiful experimental work using ${ }^{14} \mathrm{C}-D O P A$ described by S. S. Greenberg and M. J. Kopac has given more information about the pigment cell system, normal and abnormal, in xiphophorin fishes.

A number of phenolic intermediates in the formation of melanin from tyrosine are potentially cytotoxic agents, and the way in which these act was described by $P$. Hochstein and G. Cohen. The toxic effects of hydrogen peroxide (formed through the autoxidation of 3,4-dihydroxyphenylalanine) in melanomas are prevented through the action of the glutathione peroxidase pathway.

On the more purely chemical side, C. R. Dawson and W. B. Tarpley produced new evidence of the formation of $o$-benzoquinone, 1,2,4-trihydroxybenzene and hydroxyquinone as intermediates in the tyrosinase-catalysed oxidation of catechol, which results in the formation of a dark, polymeric pigment. The apparently increased stability of $o$-benzoquinone in tyrosinase systems is explained in terms of catechol reformation and re-oxidation. H. J. Bright, B. J. B. Wood and L. L. Ingraham speculated on the role of copper in tyrosinase-catalysed reactions, but more experimental support for their theory is required. G. A. Swan summarized recent work on the chemical structure of melanins, emphasizing that not all black, insoluble, naturally occurring or synthetic polymeric pigments were identical, and presented evidence of the retention of intact methylene groups from the side-chains of 3,4-dihydroxyphenethylamine or 3,4dihydroxyphenylalanine in melanins formed from these compounds under some conditions. He also indicated that 2,4,5-trihydroxyphenethylamine and 2,4,5-trihydroxyphenylalanine were unlikely to be major intermediates in the formation of melanins from the corresponding 3,4-dihydroxy-compounds, although B. Witkop expressed the view that some hydroxylation of 3,4-dihydroxyphenethylamine was likely to occur, even if only to a minor extent.

The last paper of the conference was by P. Brunet and discussed the metabolism of tyrosine in insects, leading to the formation of integumental pigments and to the formation of quinones, which are concerned in the 'tanning' of protein. This was followed by a brief, concluding speech by Dr. M. J. Kopac.

Emphasis in the biological papers seemed to be on two aspects of pigment cell biology. First, attention was directed to the melanoblast and melanocyte in their tissue relationships, responding both to local and to endocrine factors by a change of metabolic pathways; secondly, correlations between genetic and biochemical phenomena showed promise of great impacts on both subjects in the near future. On the chemical side, our very meagre knowledge of the processes leading to pigmentation was only too apparent. The conference can certainly be expected to stimulate increased and renewed effort on the medical, biological and chemical aspects of cellular pigmentation.

It was obvious from the excellent arrangements made for the conference that Drs. Riley and Fortner had devoted an enormous amount of time and energy to the organization of the conference. Its success may be judged from the fact that people were already looking forward to the possibility of a sixth.

At the conclusion of the conference, those visiting foreign participants who were able to stay were most generously entertained by Mr. Claude-Arpels at his Westchester summer home and later made a short visit to the new Walker Laboratory of the SloanKettering Institute at Rye.

\section{J. COHEN \\ G. A. Swan}

\title{
TECHNICAL CO-OPERATION UNDER THE COLOMBO PLAN
}

HE report for $1960-61$ of the Council for Tech-
nical Co-operation in South and South-East Asia,
while mainly providing a readable account of tech-
nical co-operation under the Colombo Plan during
the year, giving besides figures numerous examples
of such co-operation in economic development and in
the development of social services, includes a chapter which surveys briefly ten years of technical co-operation under that Plan*. Of the present nineteen full members of the plan, nine are members of the Commonwealth, and during the year 4,417 new

* Department of Technical Co-operation. Technical Co-operation under the Colombo Plan: Report for 1960-61 of the Council for Technical Co-operation in South and South-Erst Asia, Colom
October 1961. Pp. 68. (London: H.M.S.O., 1961.) 48. 6d. net. 
trainoes brought the total for the decade to 19,533 , while provision of 786 new experts brought the total provided under the Plan for longor or shorter poriods to 3,155 . Besides this contribution to the building up of skilled technical and administrative man-power in the region, a considerablo contribution has also boen made by the operations of other multilateral and bilateral technical assistance programmes of Governments and of private foundations and by the activity of firms and individuals who make their own arrangements for education and training abroad. Expenditure under the Plan amounted to $£ 20,197,240$, compared with $£ 16,846,586$ in $1959-60$, bringing the total to more than $£ 66$ million; of these totals $£ 5,670,310, £ 2,966,221$ and $£ 15,185,582$, respectively, wore on technical equipment; $£ 8,673,059, £ 8,600,517$ and $£ 29,965,729$ were expended on experts; and

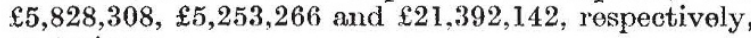
on trainees.

In spito of this substantial progress, the report emphasizes that the population of the region is probably now at least 750 million, comparod with 603.4 million in 1950 , and accordingly the provision of food, housos, schools, medical services and jobs for this increasing population has become more urgent. Still greater investment in the human resources of South and South-East Asia is needed, and stress is laid on the human problems of economic devolopment which demand wisdom and perseverance as well as money for their solution.

Of the British contribution, the report shows that the United Kingdom provided 623 new training places during the year, bringing the total under the Plan to 3,880 , as comparod with 7,112 by the United States, 3,530 by Australia, 1,617 by Canada, and 1,545 by Indis during the decade. The United Kingdom provided 42 new experts during the year, making a total of 446 for the decade, compared with 1,333 provided by the United States, 441 by Australia, 347 by Japan, 259 by Canada, 169 by India and 156 by New Zealand. The United Kingdom provided $£ 235,988$ worth of equipment during the year, making a total of $£ 2,009,788$ out of a total expenditure on technical co-operation under the Plan of $£ 7,051,433$.

The report also quotes totals of 8,267 experts and 6,023 Fellows supplied during the period by the United Nations and its specialized agencies. Of the experts supplied under the Plan itself, 475 have been in education, 507 in medicine and health, 494 in food, agriculture and forestry, 426 in enginoering, 346 in transport and communications, and 155 in administration. Reviewing the yoar 1960-61 itself, the report notes considerable increases in the number of students selected for courses in general education and an increase in the number selected under the heading industry and trade. Traineos from Ceylon, Pakistan and espocially the Philippines increased considerably in numbers as against large decreases in those from Cambodia and Laos. Provision of training places by each country remained fairly constant, the increased total being due mainly to a rise from 63 to 305 in the number of places provided by Japan, and from 70 to 158 in the number provided by Now Zoaland. The trend noted in the previous report towards rathor Ionger courses of training continued, but the figures for training within the area aro disappointing, the total of now training places declining from 309 to 286 .

Requests for equipmont sorviced during the year inclucled the supply of library books, audio-visual aids, workshop and laboratory equipment (including radio-isotope oquipment) to schools, universities, artisan training centros and trade schools; transistor radio-sets to village schools; animal vaccine produetion equipment, large doses of B.C.G. vaccine and tuberculin, and horses for production of antivonine serum to livestock and health dopartments ; and films for hoalth education work, equipment for tuberculosis control projects, and heart/lung and $\mathrm{X}$-ray equipment for cardiographic work.

Some specific examples of co-operation provided by the United Kingdom during the year cited in the report included a one-year course of training in the technology of stored products, entomology, and control of rodents for two trainees from the Philippines: training in the United Kingdom for the manager of the Bihar State Department of Agriculture and Animal Husbandry's poultry farm; equipment for the Forest Products Rosearch Institute in Cambodia and extension of the sorvices of an expert already serving there to supervise its installation; presentation to Nepal of three Diesel power-plants and a consultant on electrical distribution to advise on a reticulation system for Kathmandu; an adviser on electrical powor planning for Burma; technical assistance in the development of three underground mines in the Ranchi area, and training in the manufacture, orection and testing of high-tension switchgear for an exceutive ongineer from Orissa and in electrical power systems for the superintending engineor of the Bihar State Electricity Board to enable him to train tochnical subordinates. Advanced training has also been provided for an officer of the Madras Electricity Board and an engineer of the Electricity Directorate of East Pakistan.

An expert in fuel technology was provided for the Central Fuel Research, Dhanbad, to adviso on low. and medium-temperature carbonization of coal and for the production of domestie coke, and training provided for a research officer of the Birbal Sahni Instituto of Palæobotany. A consortium from the United Kingdom is participating with India in the Rs. 1,670 million Durgapur joint venture for the production of iron and steel, and the spinning master of the only flax weaving mill in India received training in the manufacture of linen thread and towels in Northern Ireland. Pakistan was provided with a lecturer in spinning and with equipment and books for the Institute of Textile Technology at Lyallpur. while another expert was supplied to advise on the maintenance of textile machinery. Trainees from East Pakistan came to study the juto industry, one from Ceylon to study advanced chemistry of coment. others from India, the fire-fighting at aerodromes and meteorological instruments, the building of marine works such as breakwaters and deep-sea berths. and the productive efficiency of railway workshops.

A loan of $£ 3$ million to Pakistan was made for the purchase of railway wagons, and $£ 2.5$ million to Ceylon to improve the Greater Colombo telephone system. A team of exports was suppliod to Ceylon to assist the Ceylon Transport Board, and three officers of the Board and a regional manager of the West Pakistan Transport Board received training in the United Kingdom, whilo two trainees came from India for spocial studies in highway engineoring.

A medical officor from Pakistan and three from Burma came to the Unitod Kingdom for advanced training in obstetries and gynæcology; for pædiatrics trainees came from Thailand, India, Nepal and Ceylon. The London School of Hygiene and Tropical Medicine accepted, among others, a deputy assistant 


\section{No. 4811 January 13,1962}

director of health services from West Bengal, and a deputy municipal health officer from Kuala Lumpur, Malaya, while a deputy principal health officer from Burma took a course at the Royal Institute of Public Health and Hygiene, and the professor of dental surgery, Madras Medical College, a three-year course at the Institute of Basic Medical Sciences, Royal College of Surgeons. A physicist of the Cancer Research Institute, Madras, is doing postgraduate research at the Institute of Cancer Research, London.

A lecturer in veterinary science was provided for the University of Rangoon, equipment provided to improve the teaching facilities in the Departments of Chemistry and Engineering, University of Malaya in Kuala Lumpur, and lecturers in physics from the University of Dacca were trained in radiation physics and electron microscopy. Four professors and a workshop superintendent were provided for the College of Engineering and Technology, New Delhi; ten more professors and staff are to be provided, as well as training for members of the College staff. The professor of agricultural chemistry from the only agricultural institute of degree-level in Assam is receiving higher training at the University of Leeds. and advanced training was provided for a lecturer in mechanical engineering and an assistant professor of eivil engineering from the College of Engineering and Technology as well as for the professor of plant ecology of the University of the Panjab. The Institute of Education, University of London, runs an annual nine-months course for community officers which was attended by officers from Indonesia, Laos, Thailand and Vietnam. Traineos from Burma, Malaya, Indonesia, the Philippines and Thailand attended a course in public administration at the University of Manchester, while others from Burma, Ceylon, Malaya, India, the Philippines and Thailand attended a similar course at the London School of Economics. and a student from Ceylon a course at the Adminis. tration Staff College, Henley-on-Thames.

\section{PHYCOLOGY IN BRITAIN}

$\mathrm{T}$ HE recently published number of the British Phycological Bulletin (2, No. 2; 1961) provides ample evidence of a lively interest in the study of algae in Britain. Among the varied articles and reports, special mention should be made of the presidential address by Dr. Mary Parke. This address deals mainly with recent studies of the morphology, taxonomy and life-histories of the Chrysophyceae. It is clear from the account that the electron microscope has been of great value in taxonomic studies, by revealing details of the structure of the flagella, and of the structure of the scales in the scale-bearing forms. It is of interest that, even in the small number of forms so far examined, the scales show as wide a range of structure as that found in diatom frustules.

The recent work on the life-histories of representatives of the Chrysophyceae, especially by Dr. Parke herself, emphasizes the difficulties and exciting work awaiting the student of this algal class. Investigations in culture have demonstrated that, as in other groups of algae, genera originally thought to be distinct are actually different phases of the same life-history. Thus, in clonal eultures of three different coccolithophorids from the Plymouth collection, Syracosphaera carterae, Syracosphaera sp. (not yet named) and Pleurochrysis scherffelii, non-motile stages could be matched with forms of Chrysophyceas such as Chrysosphaera marina, Apistonema sp. and $A$. pyrenigerum from the Baltic, and $A$. carteri, Chrysonema litoralis, Thallochrysis litoralis, Chrysotila stipita and $C$. lamellosa from the chrysophycean zone on the chalk cliffs near Westgate. Equivalent stages are also found in the chrysophycean zone on the chalky sandstone cliffs of St. Andrews Bay, Scotland.

In addition to the coccolithophorid life-history with an Apistonema stage, Dr. Parke mentions two other types of life-history: the Coccolithus pelagicus type with a motile Crystallolithus phase and the Ochrosphaera neapolitana type, in which the motile cells are probably of different structure. These varied life-histories suggest that the present system of classifying the coccolithophorids on the morphology of their coccoliths will prove unsatisfactory in future and that eventually the classification may have to be based on the type of life-history. Thus, while one group of coccolithophorids may produce a benthic filamentous phase, perhaps growing best on a chalky substratum on the shore, another series, like Coccolithus pelagicus, may have a non-motile cyst stage from which the motile phase is again released when conditions are suitable. Yet another series may have its non-motile phase endophytic in the wall strata of another alga or symbiotic in some animal. It is also suggested that the external control of the phases is a possibility and may be of considerable importance from the fisheries angle, particularly in the production of food for the culture and rearing of shellfish larvæ. Dr. Parke concludes that time and patience will be required to relate the many described motile phases to their non-motile stages, as well as to clear up the many nomenclatural problems that will be involved.

Other articles deal with freshwater algae. Dr. J. H. Belcher and E. M. F. Swale describe some new and uncommon British Volvocales, including a species of a new genus Myochloris. In a contribution on Asterionella formosa Hass. var. acaroides Lemm., "at phycological enigma", Dr. J. W. G. Lund refers to the fact that although millions of cells of Asterionella have been observed, no one has yet seen auxospores in this genus. It was thought possible that var. acaroides might be the auxospore stage of $A$. formosa; but after examination of the available evidence it was concluded that the nature of this variety is still uncertain.

Returning to marine algae, Dr. Peter S. Dixon and Dr. Máirín de Valera, after a critical survey of evidence for the occurrence of Gelidium torulosum Kütz and $G$. melanoideum Schousb. ex Born. in Britain and Ireland, conclude that both species must be removed from the list of indigenous species, the existing records being based entirely on misidentifications. Dr. Joanna M. Kain contributes some useful records of sub-littoral algae, sampled by use of an aqualung, both from Alderney and from two regions off the west coast of Scotland.

Shorter accounts include the identification of Compsopogon coeruleus, from the Reddish Canal near Manchester; the occurrence of resting zygotes in the Chlorophyceae, with special reference to Carteria 